\title{
How Well is the Tropical Africa Prepared for Future Physiologic Stress? The Nigerian Example
}

\section{Eludoyin OM*}

Department of Geography and Planning Sciences, AdekunleAjasin University, Akungba-Akoko, Ondo State, Nigeria

\begin{abstract}
The huge literature gap in the knowledge of physiologic climatology on tropical Africa indicates poor awareness to the issue of physiologic stress in the region. This study examined the variability in the physiologic comfort over Nigeria using both annual and hourly patterns of unitary (temperature and relative humidity) and integrative indices (effective temperature, temperature-humidity and relative strain indices), and assessed the perceptions of a randomly selected Nigerians in 18 tertiary institutions across the country. Results indicated thermal stress in Nigeria, and showed that both heat and cold stress varied temporally (annually and hourly) and spatially (1200-1500 Local Standard Time, LST as the most thermally uncomfortable period of the day, and $\leq 0900$ and around 2100 LST were more comfortable). Perception of the comfortable climate exhibits variation based on the latitudinal location of the respondents but the coping strategies vary with the wealth of individuals. The study indicated that whilst many parts of Nigeria could be vulnerable to physiologic stress, indigenous and modern know-how to cope with future physiologic stress is largely unknown. The study therefore recommends significant improvement in climate-oriented policies, especially in the areas of healthcare and infrastructure.
\end{abstract}

Keywords: Day-time thermal comfort; Coping strategies; Effect of extreme weather; Climate education

\section{Introduction}

Physiologic climatology is a field of scientific study that is concerned with the effects of climatic elements and patterns on the physiologic behaviour of man and other warm blooded animals [1-3]; and with classification or regionalisation of climatic environments based on measurable human psychological and physiologic reactions [4]. Researches on the effects of climate on human's feelings and behaviour have increased in recent times, probably because of the increased concerns for extreme climate conditions and their consequences on human health and livelihood [5,6]. Available social, health, economic and technological facilities in many vulnerable communities are also inadequate to mitigate the negative effects of extreme climate conditions $[7,8]$.

Two classes of approaches- unitary and integrative- are generally available in literature as indicators of physiologic comfort. The unitary approach considers certain elements of climate (temperature, humidity, radiant energy and air movement or wind) as suitable indicators of physiologic climate per unit time [1]. The setback to the unitary concept is that the climate factors that are usually linked with human physiology are rarely excusive but are rather integrative $[9,10]$. The integrative approach demonstrates that humans respond physiologically to more than one element of climate at a time $[11,12]$, and as such indicators which combine, extrinsically, at least two elements of climate are more realistic. A better approach has been to combine both unitary and integrative approaches, complementarily. For example, Terjung $[4,13]$ characterised the physiologic comfort in the African and North American (contiguous) continents from two main integrative indices the comfort index (an integration of dry bulb temperature and relative humidity) and wind effect index (a combination of solar radiation and wind chill)- complementarily; the wind effect index complemented the comfort index where wind was considered to be of little or no effect. Similarly, Gregorczuk and Cena [14] mapped the physiologic comfort of the world using the effective temperature index (ETI). The ETI is one of the oldest indices for illustrating the physiologic comfort, though previously designed for indoor condition, that have gained interests among scholars in the tropics that, probably because they have found the index relevant to the region [14-17]. More recent studies [18,19] have indicated the use of more integrative indices in Nigeria - a typical tropical country- and these also include the temperature-humidity index (THI) and relative strain index (RSI), as applied in other countries such as Hungary [11] and Argentina [20]. Other indices such as apparent temperature (AT), predicted mean vote (PMV) are among the over one hundred integrative indices that have been used in literature [21-24].

Whilst information generated from the analysis of physiologic comfort have been found useful for planning of holidays, migration, tourism and building in many countries [25,26], African countries have appeared to show less interest in the aspect of climatological research; most African researches in climate science and applications have focused on ensuring food security. On the other hand, the increasing population and urbanisation rate in Africa, as well as indications of temperature increase due to anthropogenic factors (such as gas flaring and oil exploration activities) are justified reasons to study the change in the physiologic comfort in the area [27].

Few studies $[17,28]$ have however provided information on the daytime variability of physiologic comfort in any part of Africa- the studies are on Nigeria- and these studies require updating [28] was a microscale study on Ilorin in the guinea savanna part of Nigeria). The present study compares the 1971 and 2001 weather of selected meteorological stations in Nigeria as a complement to the study of the

*Corresponding author: Eludoyin OM, Department of Geography and Planning Sciences, AdekunleAjasin University, Akungba-Akoko, Ondo State, Nigeria, Tel: +2348037775506; E-mail: baynick2003@yahoo.com

Received September 15, 2014; Accepted January 06, 2015; Published January 08, 2015

Citation: Eludoyin OM (2015) How Well is the Tropical Africa Prepared for Future Physiologic Stress? The Nigerian Example. J Climatol Weather Forecasting 3: 133. doi:10.4172/2332-2594.1000133

Copyright: @ 2015 Eludoyin OM, et al. This is an open-access article distributed under the terms of the Creative Commons Attribution License, which permits unrestricted use, distribution, and reproduction in any medium, provided the original author and source are credited. 
59 year (1951-2009) average data of physiologic comfort. The study also sought insight into the indigenous perception of both indoor and outdoor workers in selected tertiary institutions across Nigeria. Perception on physiologic comfort is known to be subjective factors such as types of clothing wears used to cover the skin covers, previous weather experience and certain adaptation factors, including culture and body type [29-31]. The overall goal is to determine the average change in physiologic stressed based on daytime variation and assess the knowledge of efficient coping strategies in case of an endangering physiologic stress.

\section{Study Area}

Nigeria is located within $4-14^{\circ} \mathrm{N}$ and $3-15^{\circ} \mathrm{E}$ in the southeastern edge of the West African region, and is characterized by dry season (usually accompanied by the tropical continental airmass influenced dust-laden or Harmattan wind from the Sahara desert) and rainy season (which is strongly influenced by the tropical maritime from the Atlantic Ocean. The Nigerian climate can be grouped into: the tropical rainforest climate, tropical savanna climate and highland climate or montane climate [32]. The tropical rainforest climate ('Af' by Köppen climate classification) characterises the southern region, and can be sub-grouped into the tropical wet and tropical wet and dry climates while the Tropical savanna climate comprises the guinea, sudan and sahel savanna, and characterizes most of the central and northern regions. The guinea belt occupies the limits of tropical rainforest climate, and extends to the central part while the northern fringe is occupied by the sudan tropical savanna climate. The north-eastern fringes exhibit the sahelian climate while the montane climate occurs in settlements on high altitude (especially above 1520 $\mathrm{m}$ as in the Plateau Mountains) (Figure 1). A little less than 50\% of the above 100 million Nigerian populations live in the urban areas as 2010 (Table 1). The rural population, which contains about $50 \%$ of the remaining population in Nigeria is however characterised by poor infrastructure, including poor access to healthcare system, education and communication facilities. The poor electricity in Nigeria also made many people to be vulnerable to heat stress and other environmental impact, typical of developing countries in Africa, Asia and Latin America [8].

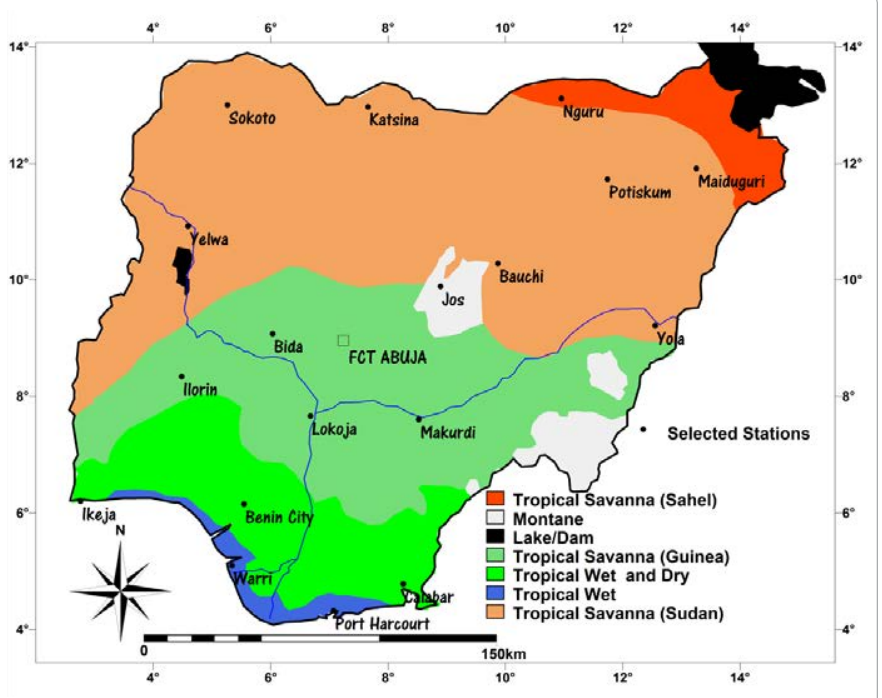

Figure 1: Distribution of meteorological stations selected for the study

\begin{tabular}{|c|c|c|}
\hline Variables & Specifics & Rate \\
\hline \multirow{3}{*}{ Landuse } & Deforestation & 4000 sq. km per year \\
\hline & Reforestation & 10 sq. km per year \\
\hline & Forested area (2008) & $10.8 \%$ \\
\hline \multirow{2}{*}{$\begin{array}{c}\text { Urban } \\
\text { Population }\end{array}$} & Annual growth & $3.8 \%$ \\
\hline & Urban Population in 2004, 2010 & $45 \%, 48.9 \%$ \\
\hline $\begin{array}{c}\text { Rural } \\
\text { Population }\end{array}$ & Annual growth & $1.8 \%$ \\
\hline \multirow{2}{*}{$\begin{array}{c}\text { Total } \\
\text { population }\end{array}$} & Population density in 2004, 2009 & $137.6,167.5$ persons per $\mathrm{km}$ \\
\hline & Annual growth & $2.5 \%$ \\
\hline $\begin{array}{l}\text { Total fossil } \\
\text { fuels } \\
\text { emission }\end{array}$ & $\begin{array}{l}1951 \\
1980 \\
2008\end{array}$ & $\begin{array}{c}460^{\prime} 000 \text { metric tons } \\
18,586 \text { '000 metric tons } \\
26113^{\prime} 000 \text { metric tons }\end{array}$ \\
\hline
\end{tabular}

Table 1: Some information about land area and population of Nigeria (2011 World Statistics Country Profile).

\section{Materials and Methods}

Two types of data sources were used for this study. The first sets of data were the temperature and relative humidity data, which were obtained from the Nigerian Meteorological (NIMET) Stations' office, Lagos. The NIMET office in Lagos is a custodian of the quality assured climate data obtained from all the meteorological stations across Nigeria. The meteorological stations, located at least in each State and in other areas of specialized government (and colonial) interests make up of about 56 stations out of which less than 20 possessed temperature and relative humidity data from 1951, although most of the stations have long-term (pre-1951) rainfall data. Selected integrative indices required data on temperature and relative humidity, hence only meteorological stations with these data were selected. For representativeness, a network of $2^{\circ}$ by $2^{\circ}$ grid was overlayed on the map of Nigeria, and a representative station was selected for each grid, where possible. Since only daytime $(0600,0900,1200,1500,1800$ and 2100 hour) temperature and relative humidity data were available (because data were collected at 3 hour interval), this study used only the daytime (0600-2100 Local Standard Time, LST) relative humidity and temperature data for 20 meteorological stations to compute the selected thermal comfort indices (effective temperature index, temperaturehumidity index and relative strain index) (Figure 1). Selected thermal comfort indices are described in Box 1. The 20 stations were selected to represent the different sub-climate types (tropical wet (Port Harcout, Warri); tropical wet and dry (Ikeja, Benin and Calabar); guinea savanna (Bida, Ilorin, Lokoja, Makurdi); sudan savanna (Katsina, Sokoto, Maiduguri, Potiskum, Bauchi, Yola and Yelwa); sahel savanna (Nguru); and montane (Jos)) (Figure 2). Day-time thermal comfort for 1971 and 2001 was also compared to provide experience for typical cool and warm year thermal comfort for Nigeria (the choice of 1971 and 2001 was based on the global temperature model [33] and data availability).

Values for the investigated meteorological stations and periods were interpolated using the moving averages technique to plot the descriptive maps for Nigeria, and the monthly day-time thermal comfort for selected stations with standard geographic information (ILWIS, version 3.4, and a third party, SURFER) software. Classification of the physiologically comfortable (ETI values of $18.9^{\circ}-25.6^{\circ} \mathrm{C}$ or THI values of $15^{\circ}-24^{\circ} \mathrm{C}$ or RSI values of $0.1-0.2$ (ratio, no unit)) and regions that exhibited cold or heat stress condition (cold stress occurs at values below the minimum while the maximum threshold marks the beginning of a heat stress condition) were determined based on the information in Box 1.

Secondly, preference and responses of Nigerians on thermal 


\section{Effective Temperature Index}

The effective temperature index (ETI) was originally intended for indoor conditions in industry and mines and not for open air conditions (Gregorczuk and Cena, 1967) but has later gained wider applications in comfort and climatological analyses in north America and Europe. The results of ETI represent the thermal sensations of a man insulated from air movement and from solar radiation. Values of ETI is usually estimated as (1-2).

$$
T_{e t i}=t-0.4(t-10)\left(1-\frac{H_{r h}}{100}\right) \quad(1), \quad T_{e t i}=0.4\left(t_{d r y}+t_{w e t}\right)+4.8
$$

Where

$T_{\text {eti }}=$ effective temperature, $t=$ air temperature, $H_{r h}=$ relative humidity, $t_{d r y}=$ dry bulb temperature, ${ }^{t_{\text {wet }}}=$ wet bulb temperature.

Uncomfortable situations due to cold stress occur with ETI $\leq 18.9^{\circ} \mathrm{C}$ and heat stress $>25.6^{\circ} \mathrm{C}$ (Ayoade 1978). Challenges with ETI are; that the basic observations on the original model development were made on a specific group of subjects; healthy young white men and women living under American conditions of climate, housing and clothing, the observation relate only to sedentary conditions; and that the index in its original form gives too much weight to changes in humidity at the lower end of the Comfort index scale.

\section{Temperature-Humidity Index (THI)}

The THI was developed by Thom (1959) for providing a broad approximation of stress changes in a city over time and for developing useful design guidelines for cities (Jáuregui and Soto, 1967). The original index, which combined the wet and dry bulb temperatures to produce the THI, has been modified by McGregor and Nieuwolt (1998) to use air temperature and relative humidity (3)

$$
\mathrm{T}_{\mathrm{thi}}=0.8 * t+\frac{H_{r h} * t}{500}
$$

Where

$T_{\text {thi }}=$ Temperature-humidity index, $t$ is the air temperature $\left({ }^{\circ} \mathrm{C}\right)$ and $H_{r h}$ is the relative humidity $(\%)$.

Nieuwolt (1977) suggested the following THI classification, based on the climate of the United States of America and suggestion of the United States Weather Bureau (1959).

a. $21-24^{\circ} \mathrm{C}=100 \%$ of the subjects felt comfortable

b. $24-26{ }^{\circ} \mathrm{C}=50 \%$ of the subjects felt comfortable

c. THI $>26^{\circ} \mathrm{C}=100 \%$ of the subjects felt uncomfortably hot

\section{Relative Strain Index (RSI)}

In order to take account of the effects of clothing and net radiation, the relative strain index (RSI) was developed for a sedentary standard man dressed in a business suit (healthy, 25 years old and not acclimatized to heat) (Giles et al., 1990; Lee, 1953). The RSI is the ratio of the rate at which heat accumulates in the body of one organism to the maximum possible rate at which it can be removed.

The RSI is expressed in the equations (3-5)

$$
T_{r s i}=\frac{(t-21)}{(S 8-e)}
$$

(3), $e=\frac{\left(H_{r h} \times H_{v p}\right)}{100}$

(4),

$$
R S I=\frac{[10.7+0.74(T-35)]}{44-0.0075 H V}
$$

\section{Where}

$$
V=6.11 \times 10^{\frac{7.5 T}{237.7+T}}
$$

$T_{r s i}=$ Relative Strain Index, $H_{v p}=$ Vapour pressure (hPa), $H_{r h}=$ Relative humidity (\%), $t=$ air temperature $\left({ }^{\circ} \mathrm{C}\right)$, and $e=$ Dew point temperature. The RSI threshold for physiological failure is 0.5 for young people and 0.3 for people older than 65 years (Giles et al., 1990). A quarter of the people would be uncomfortable at an RSI of 0.2 and no one is comfortable at an RSI of 0.3 . For elderly and ill people, 0.2 is the threshold above which they are subject to heat stress. 


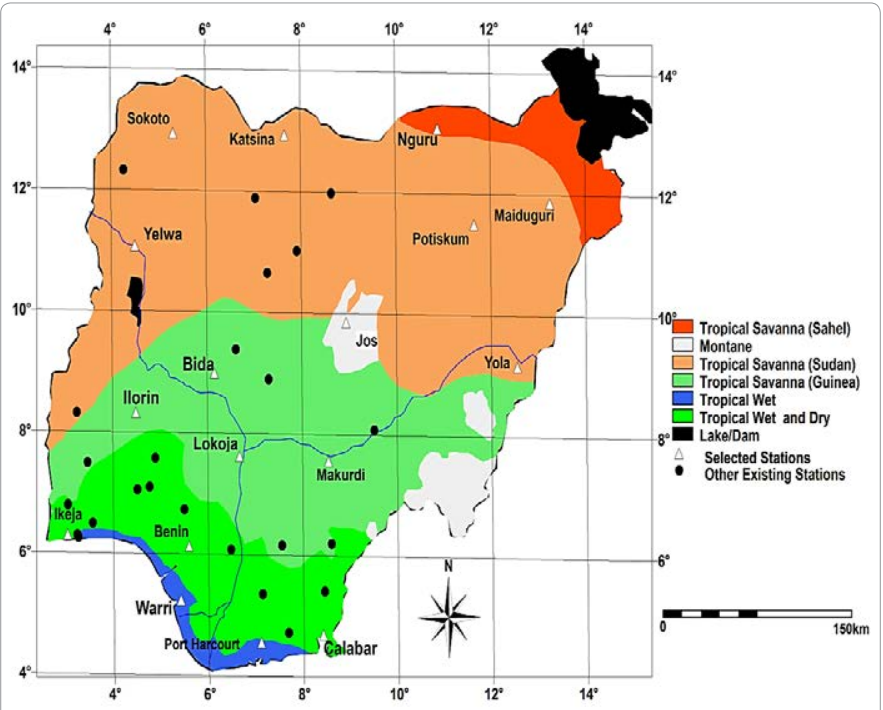

Figure 2: Climate sub-regions in Nigeria showing the location of selected meteorological stations.

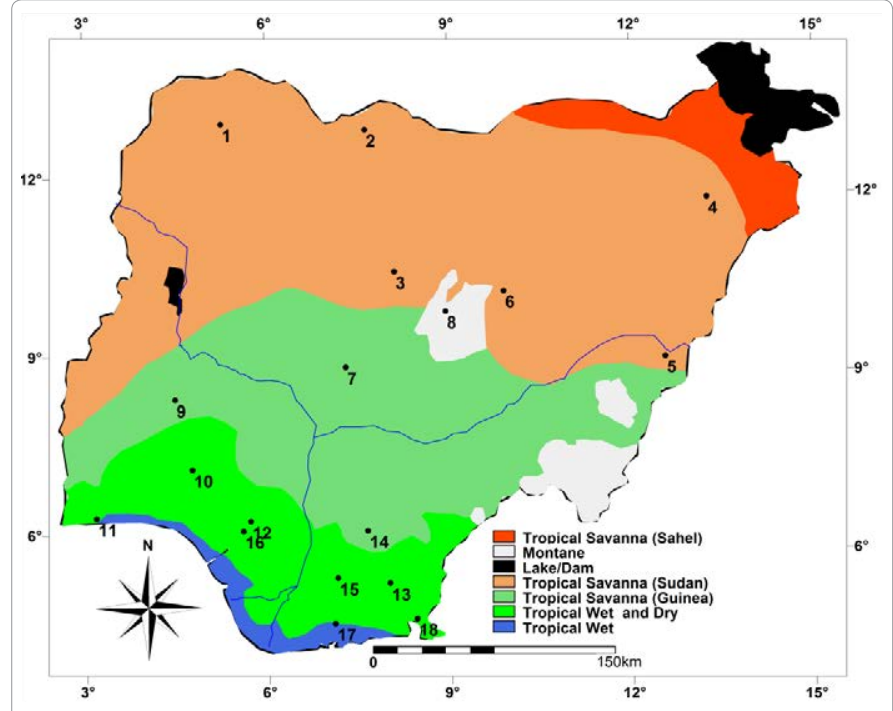

1. Usman Dan Fodio University Sokoto 10. Obafemi Awolowo University, lle-lfe

2. Hassan Usman Katsina Polytechnic 11. University of Lagos

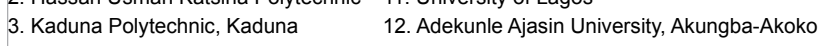

4. University of Maiduguri 13. Abia State University

5. Federal University of Technology, Yola14. Enugu State University

6. Federal Polytechnic, Bauchi 15. Imo State University

$\begin{array}{ll}\text { 7. University of Abuja } & 16 \text {. University of Benin }\end{array}$

8. University of Jos 17. University of Port Harcourt

9. University of llorin 18. University of Calabar

Figure 3: Locations where questionnaire were administered for this study.

comfort was assessed by administering a set of questionnaire to about 200 randomly selected workers from each of purposively selected 18 tertiary (University, Polytechnic, or College of Education) locations in Nigeria (Figure 3).

Crocombe and Malama (1989) had argued that the responses from a tertiary institution could sometimes be stronger than that of a community, probably because those in schools are likely to be more conscious and inquisitive than others within the entire community. To determine the sampled population the Slovin's formula (equation 7) was applied for a targeted population of 10,000 in each institution.

$$
\text { Sample population }=\frac{N}{1+N e^{2}}
$$

\section{$\mathrm{N}=$ total targeted population, $\mathrm{e}=$ confidence level $(0.05$ for $95 \%)$}

A sample size of 200 was finally accepted because less than the targeted sample sizes for most institutions were returned.Almost $60 \%$ of the respondents worked indoor while $40 \%$ worked outdoor. Most of the respondents were adults between the ages of 18 and 60 years, who worked either on full or part time basis at the sample locations. The 18-60 years age group makes up the most productive set of the population. More than $70 \%$ of the respondents had lived in the sample location for at least 5 years and this gives the group an advantage of fair understanding of the climate of the sample location. More than $99 \%$ of the respondents had attained at least primary education status (and $67.5 \%$ have had tertiary or post-secondary education), suggesting that they would easily understand the content of the questionnaire and its purpose. At least, $40 \%$ of the workers claimed to make a minimum of five hundred thousand (500,000 Naira) per annum; an equivalent of about US $\$ 9$ per day as at the time of the research.

\section{Results}

\section{Characterisation of the Nigerian thermal climate conditions}

\section{i. Mean values and variability}

The 59-year (1951-2009) average minimum, maximum and mean temperatures in Nigeria (based on the selected 20 stations) are 21.4, 32.8 and $27^{\circ} \mathrm{C}$, respectively (Table 2). Table 2 also indicated that minimum temperatures were generally below the overall mean in the tropical savanna (except at Sokoto and Yola) and montane regions while mean maximum temperature in all stations within the savanna was higher than its overall mean, except at Bauchi and Ilorin. The montane, tropical wet and dry and tropical wet climate regions, however, had lower (than the overall average) mean maximum temperature. The mean relative humidity varied between 36.5 and $85.1 \%$, with $62 \%$ as the mean. Variations in both temperature and relative humidity increased from south towards the north, except for few stations in the guinea and sudan savanna which exhibited higher variability than the sahel. Lowest mean annual ETI occurred at the montane region (Jos, $\left.19.4^{\circ} \mathrm{C}\right)$ while the highest values occurred at Warri in the tropical wet climate $\left(26.1^{\circ} \mathrm{C}\right)$. Annual ETI values at most of the stations within the sudano-sahelian and montane (Jos) climate regions are lower than the overall average $\left(24.3^{\circ} \mathrm{C}\right)$. Stations within the guinea savanna, and tropical rainforest on the other hand, exhibited higher ETI than the overall average. Highest mean THI $\left(26.3^{\circ} \mathrm{C}\right)$ occurred in Lokoja (Guinea savanna) while the montane station exhibited the lowest $\left(19.6^{\circ} \mathrm{C}\right)$ mean THI. Highest RSI ratio (0.2) occurred at Warri in the Tropical wet climate while the montane region exhibited the smallest ratio (0.01) (Table 2).

ii. Trends in the unitary (temperature, relative humidity) and integrative indices

The results of linear regression analysis and their level of significance for each variable and at the investigated stations indicated that temperature variables and the integrative indices exhibited significantly increasing trend at most stations, except the montane and few stations in the savanna. Both minimum and mean temperatures exhibited decreasing trends at the montane region, while maximum temperature at Yelwa has increased. 


\begin{tabular}{|c|c|c|c|c|c|c|c|c|c|c|c|c|c|c|c|}
\hline \multirow{3}{*}{ Climate region } & \multirow{3}{*}{$\begin{array}{l}\text { Meteorolo- } \\
\text { gical Station }\end{array}$} & \multicolumn{6}{|c|}{ Temperature $\left({ }^{\circ} \mathrm{C}\right)$} & \multirow{2}{*}{\multicolumn{2}{|c|}{$\begin{array}{l}\text { Relative Humidity } \\
\text { (\%) }\end{array}$}} & \multirow{2}{*}{\multicolumn{2}{|c|}{ ET $\left({ }^{\circ} \mathrm{C}\right)$}} & \multirow{2}{*}{\multicolumn{2}{|c|}{ THI ( $\left.{ }^{\circ} \mathrm{C}\right)$}} & \multirow{2}{*}{\multicolumn{2}{|c|}{ RSI (ratio) }} \\
\hline & & \multicolumn{2}{|c|}{ Minimum } & \multicolumn{2}{|c|}{ maximum } & \multicolumn{2}{|c|}{ Mean } & & & & & & & & \\
\hline & & M & SD & M & SD & M & SD & M & SD & M & SD & M & SD & M & SD \\
\hline $\begin{array}{l}\text { Tropical Savanna } \\
\text { (Sahel) }\end{array}$ & Nguru & 21.2 & 4.4 & 35.3 & 3.6 & 28.2 & 3.5 & 36.5 & 21.1 & 23.1 & 1.5 & 24.2 & 1.5 & 0.17 & 0.05 \\
\hline \multirow{7}{*}{$\begin{array}{l}\text { Tropical Savanna } \\
\text { (Sudan) }\end{array}$} & Katsina & 19.4 & 4.3 & 33.7 & 3.4 & 26.5 & 3.5 & 38.9 & 23.5 & 22.5 & 0.6 & 23.3 & 0.6 & 0.13 & 0.02 \\
\hline & Sokoto & 22.0 & 3.6 & 35.2 & 3.2 & 28.6 & 3.0 & 42.7 & 23.6 & 24.4 & 0.6 & 25.4 & 0.6 & 0.19 & 0.03 \\
\hline & Maiduguri & 20.1 & 4.6 & 35.3 & 3.6 & 27.7 & 3.6 & 39.9 & 20.7 & 23.5 & 0.6 & 24.4 & 0.6 & 0.16 & 0.02 \\
\hline & Potiskum & 19.7 & 4.5 & 34.4 & 3.3 & 27.0 & 3.4 & 39.5 & 23.9 & 22.4 & 1.3 & 23.3 & 1.2 & 0.13 & 0.10 \\
\hline & Yelwa & 21.3 & 3.6 & 34.1 & 3.0 & 27.7 & 2.3 & 60.7 & 19.1 & 24.9 & 0.5 & 25.5 & 0.7 & 0.18 & 0.06 \\
\hline & Bauchi & 19.0 & 3.5 & 32.7 & 2.8 & 25.8 & 2.6 & 46.7 & 23.1 & 22.4 & 0.7 & 23.1 & 0.7 & 0.09 & 0.10 \\
\hline & Yola & 21.7 & 3.2 & 34.7 & 3.1 & 28.2 & 2.4 & 55.2 & 23.5 & 24.9 & 0.9 & 25.7 & 0.9 & 0.21 & 0.05 \\
\hline Montane & Jos & 16.0 & 2.3 & 27.6 & 2.3 & 21.8 & 1.7 & 50.0 & 25.9 & 19.4 & 0.3 & 19.6 & 0.4 & 0.01 & 0.01 \\
\hline \multirow{4}{*}{$\begin{array}{l}\text { Tropical Savanna } \\
\text { (Guinea) }\end{array}$} & Bida & 22.8 & 1.8 & 33.7 & 2.8 & 28.3 & 1.9 & 64.4 & 18.1 & 25.5 & 0.8 & 26.1 & 0.6 & 0.21 & 0.06 \\
\hline & Ilorin & 21.3 & 1.7 & 32.2 & 2.6 & 26.8 & 1.6 & 74.4 & 11.6 & 24.4 & 0.5 & 24.9 & 0.5 & 0.17 & 0.02 \\
\hline & Lokoja & 22.8 & 2.0 & 33.0 & 2.4 & 27.9 & 1.7 & 73.4 & 8.2 & 25.9 & 0.7 & 26.3 & 0.6 & 0.22 & 0.04 \\
\hline & Makurdi & 22.3 & 2.5 & 33.3 & 2.6 & 27.8 & 1.8 & 69.8 & 14.2 & 25.4 & 0.9 & 25.9 & 0.7 & 0.21 & 0.04 \\
\hline \multirow{3}{*}{ Tropical Wet and Dry } & Ikeja & 23.1 & 1.3 & 30.9 & 1.9 & 27.0 & 1.4 & 82.6 & 5.8 & 25.3 & 0.6 & 26.1 & 0.6 & 0.21 & 0.04 \\
\hline & Benin & 23.0 & 0.8 & 31.3 & 2.0 & 27.1 & 1.4 & 83.9 & 5.7 & 25.9 & 0.6 & 26.1 & 0.6 & 0.21 & 0.04 \\
\hline & Calabar & 22.8 & 1.0 & 30.6 & 1.8 & 26.8 & 1.2 & 85.1 & 5.0 & 25.7 & 0.9 & 25.9 & 0.8 & 0.19 & 0.09 \\
\hline \multirow{2}{*}{ Tropical Wet } & Warri & 23.1 & 0.9 & 31.4 & 1.8 & 27.3 & 1.2 & 83.9 & 4.8 & 26.1 & 0.4 & 26.3 & 0.9 & 0.22 & 0.02 \\
\hline & Port Harcourt & 22.4 & 1.2 & 31.1 & 1.8 & 26.7 & 1.1 & 83.4 & 5.5 & 25.6 & 0.4 & 24.8 & 2.1 & 0.20 & 0.03 \\
\hline Overall mean & & 21.4 & 3.4 & 32.8 & 3.4 & 27.0 & 2.8 & 62.0 & 24.8 & 24.1 & 0.9 & 24.8 & 1.8 & 0.20 & 0.18 \\
\hline
\end{tabular}

Table 2: Descriptive statistics of temperature, relative humidity and thermal climate at selected meteorological stations in Nigeria (M represents mean, and SD is the standard deviation).

On the other hand, trends of temperatures, relative humidity has decreased in most regions, especially in the tropical rainforest region $(b \geq-0.07 ; p<0.05)$. Bauchi in the sudan savanna region however exhibited significant increase $(b=0.17 ; p<0.05)$ within the study period. Similarly, ETI, THI and RSI exhibited increased trend at most of the stations, especially within the sudan and sahelian savanna as well as tropical rainforest regions (Table $3 \mathrm{a}$ and $3 \mathrm{~b}$ ).

\section{iii. Daytime thermal comfort}

Evaluated thermal indices (THI, ETI and RSI) showed temporal and spatial variations. Peak of the heat stress condition occurred at 1500 Local Standard Time (LST) while the early morning time (before 0900 LST) were more conducive (Figure 4). Figure 4 also shows that the monthly variations of thermal comfort at selected settlements in Nigeria exhibited spatial variations. The results of ETI and RSI were similar, and therefore only ETI and THI are presented. In both ETI and THI, Lokoja (in the guinea savanna) showed most day-time hours of heat stress (1100-1700 LST) while Jos (montane region) exhibited the least number of hours with day-time thermal stress condition. Calabar and Benin (tropical wet) exhibited heat stress in the afternoon (1200-1700 LST) in June-October. Heat stress at the tropical wet regions occurred for more hours (1000-1700 LST) between November and April.

When compared, thermal comfort in 1971 exhibited slight difference from that of 2001, especially at 0900 LST and 2100 LST (Figure 5). Some of regions (in the northwest) that were mapped to experience cold stress in 1971 were comfortable (some have also exhibited heat stress) in 2001. The tropical wet region also have shown increased level of heat stress around 0900 LST. The ETI map suggests that cold stress condition extended further around the montane region. The results of the comparison also indicated a prevalence of cold stress in a typical cool year, and heat stress in a warm year.

\section{Responses of Nigerians to thermal climate}

Whilst the perceptions of sampled Nigerians varied on the seasonal distributions of heat stress ( $p \leq 0.05$ for dry season, $p \geq 0.05$ for Harmattan and rain season), about $50 \%$ from southern (tropical wet) and northern (savanna) regions described the dry season as generally warm and characterized by heat-related morbidity, including headache and heat rash. The Harmattan was described by most respondents $(>70 \%)$ as dusty, windy and linked with dry eyes, dry skin and dry throat while the rainy season is generally cool (and in some cases, cold) and linked with severe cold, headache and cough. About $90 \%$ of the sample populations responded to heat stress condition mainly by alternating their modes of dresses (from thick to thin layered dress in dry season or vice versa in the rainy and Harmattan season. Majority (>64\%) also cover their head and arms as response to the dusty Harmattan or severe cold in both Harmattan and rainy season) (Figure 6). While alternating different dressing mode to cope with a prevailing weather is a practice worldwide, people whose income is above the poverty level (the poor is defined here as those whose concern is primarily on feeding themselves and families) prefer to install air conditioners in their car, house and office (or at least in one of them) in the present study.

Figure 7 shows the preference for meeting the thermal discomfort challenges in the offices and houses. At least $70 \%$ of the entire respondents were however not disturbed about the seasonal variations in the thermal comfort as more than half of the respondents (51\%) largely attributed climate change to 'what only god can change' or 'what god uses to punish the people where he is angry with them'.

\section{Discussion}

Main objective of this study was to assess physiologic comfort across Nigeria and determine if Nigerians are well prepared to cope with future physiologic stress. The study indicated significant variability and 
Citation: Eludoyin OM (2015) How Well is the Tropical Africa Prepared for Future Physiologic Stress? The Nigerian Example. J Climatol Weather Forecasting 3: 133. doi:10.4172/2332-2594.1000133

Page 6 of 11

Table 3a: Linear trends in the unitary (temperature and relative humidity) (3a) and integrative indices (3b) in selected stations in Nigeria.

\begin{tabular}{|c|c|c|c|c|c|}
\hline \multirow{2}{*}{ Climate Region } & \multirow{2}{*}{ Stations } & \multicolumn{3}{|c|}{ Temperature $\left({ }^{\circ} \mathrm{C}\right)$} & \multirow{2}{*}{ Relative Humidity (\%) } \\
\hline & & Minimum & Maximum & Mean & \\
\hline Tropical Savanna (Sahel) & Nguru & $19.98+0.04(x)^{\star}$ & $34.67+0.02(x)$ & $27.32+0.03(x)^{*}$ & $36.75-0.01(x)$ \\
\hline \multirow{7}{*}{ Tropical Savanna (Sudan) } & Katsina & $18.82+0.02(x)$ & $33.11+0.02(x)^{*}$ & $25.97+0.02(x)^{*}$ & $41.65+-0.1(x)$ \\
\hline & Sokoto & $20.38+0.01(x)^{*}$ & $34.6+0.02(x)^{*}$ & $27.47+0.03(x)^{*}$ & $40.76+0.06(x)$ \\
\hline & Maiduguri & $19.34+0.02(x)$ & $35.04+0.01(x)$ & $26.85+0.03(x)$ & $42.81-0.09(x)$ \\
\hline & Potiskum & $18.45+0.04(x)^{*}$ & $33.42+0.03(x)^{*}$ & $25.95+0.03(x)^{*}$ & $40.76-0.04(x)$ \\
\hline & Yelwa & $20.96+0.01(x)$ & $34.81-0.03(x)^{\star}$ & $26.89-0.01(x)$ & $60.02+0.03(x)$ \\
\hline & Bauchi & $17.82+0.04(x)^{*}$ & $32.17+0.02(x)^{*}$ & $24.99+0.03(x)^{*}$ & $41.97+0.17(x)^{*}$ \\
\hline & Yola & $20.77+0.04(x)^{*}$ & $34.36+0.01(x)$ & $27.56+0.02(x)^{*}$ & $53.99+0.04(x)$ \\
\hline Montane & Jos & $17.19-0.03(x)^{*}$ & $27.01+0.02(x)^{*}$ & $21.85-0.002(x)$ & $44.72+0.16(x)$ \\
\hline \multirow{4}{*}{$\begin{array}{l}\text { Tropical Savanna } \\
\text { (Guinea) }\end{array}$} & Bida & $22.27+0.02(x)$ & $33.05+0.02(x)^{*}$ & $22.66+0.02(x)^{*}$ & $66.76-0.09(x)$ \\
\hline & Ilorin & $20.42+0.03(x)^{*}$ & $32.74-0.02+(x)$ & $26.58+0.01(x)$ & $75.99-0.05(x)$ \\
\hline & Lokoja & $22.45+0.01(x)^{*}$ & $32.59+0.02(x)^{*}$ & $27.52+0.01(x)^{*}$ & $72.44-0.07(x)^{\star}$ \\
\hline & Makurdi & $21.18+0.03(x)^{*}$ & $32.52+0.02(x)^{\star}$ & $27.19+0.02(x)$ & $71.55-0.05(x)$ \\
\hline \multirow{3}{*}{ Tropical Wet and Dry } & Ikeja & $21.65+0.05(x)^{*}$ & $30.25+0.02(x)^{*}$ & $25.95+0.04(x)^{*}$ & $86.28-0.13(x)^{*}$ \\
\hline & Benin & $22.63+0.01(x)^{*}$ & $30.68+0.02(x)^{*}$ & $26.26+0.03(x)^{*}$ & $84.87-0.03(x)^{*}$ \\
\hline & Calabar & $21.79+0.04(x)^{*}$ & $29.96+0.02(x)^{*}$ & $26.29+0.02(x)^{*}$ & $86.55-0.04(x)^{*}$ \\
\hline \multirow{2}{*}{ Tropical Wet } & WWarri & $22.39+0.03(x)^{*}$ & $31.16+0.01(x)^{*}$ & $26.77+0.02(x)^{*}$ & $84.85-0.03(x)^{*}$ \\
\hline & Port Harcourt & $21.79+0.02(x)^{*}$ & $30.17+0.03(x)^{*}$ & $25.98+0.02(x)^{*}$ & $84.56-0.03(x)$ \\
\hline
\end{tabular}

Linear trend of the asterisked $\left(^{*}\right)$ row is significant at the corresponding station within $95 \%$ confidence level $(p \leq 0.05)$

Table 3b: Linear trends in thermal comfort indices in selected stations in Nigeria.

\begin{tabular}{|c|c|c|c|c|}
\hline Climate Region & Stations & Effective temperature $\left({ }^{\circ} \mathrm{C}\right)$ & $\begin{array}{c}\text { Temperature-humidity index, } \\
\text { THI }\left({ }^{\circ} \mathrm{C}\right)\end{array}$ & $\begin{array}{l}\text { Relative strain index, RSI } \\
\text { (no unit) }\end{array}$ \\
\hline Tropical Savanna (Sahel) & Nguru & $21.46+0.06(x)^{*}$ & $22.64+0.05(x)^{*}$ & $0.17+0.0001(x)$ \\
\hline \multirow{7}{*}{ Tropical Savanna (Sudan) } & Katsina & $22.45+0.001(x)$ & $25.11+0.005(x)$ & $0.13-0.0003(x)$ \\
\hline & Sokoto & $23.44+0.03(x)^{*}$ & $24.27+0.033(x)^{*}$ & $0.15+0.001(x)^{*}$ \\
\hline & Maiduguri & $23.49+0.0001(x)$ & $24.27+0.003(x)$ & $0.14+0.001(x)^{*}$ \\
\hline & Potiskum & $20.70+0.06(x)^{*}$ & $21.71+0.05(x)^{*}$ & $0.04+0.003(x)$ \\
\hline & Yelwa & $24.90-0.01(x)$ & $25.67-0.007(x)$ & $0.21-0.0001(x)$ \\
\hline & Bauchi & $21.61+0.03(x)^{*}$ & $22.18+0.03(x)^{*}$ & $0.07+0.001(x)$ \\
\hline & Yola & $24.07+0.03(x)^{\star}$ & $24.72+0.03(x)^{*}$ & $0.15+0.0002(x)^{*}$ \\
\hline Montane & Jos & $19.31+0.003(x)$ & $19.41+0.006(x)$ & $0.01+0.0001(x)$ \\
\hline \multirow{4}{*}{ Tropical Savanna (Guinea) } & Bida & $25.64-0.01(x)$ & $25.98+0.003(x)$ & $0.22+0.0001(x)$ \\
\hline & Ilorin & $24.77-0.01(x)$ & $25.12-0.006(x)^{*}$ & $0.17+0.0001(x)$ \\
\hline & Lokoja & $25.90+0.001(x)$ & $26.27+0.003(x)$ & $0.22-0.0001(x)$ \\
\hline & Makurdi & $25.59-0.006(x)$ & $25.87+0.001(x)$ & $0.21+0.0001(x)$ \\
\hline \multirow{3}{*}{ Tropical Wet and Dry } & Ikeja & $24.59+0.03(x)^{*}$ & $25.26+0.03(x)^{*}$ & $0.16+0.002(x)^{*}$ \\
\hline & Benin & $25.14+0.03(x)^{*}$ & $25.25+0.03(x)^{*}$ & $0.17+0.002(x)^{*}$ \\
\hline & Calabar & $25.89-0.01(x)$ & $25.98-0.002(x)$ & $0.21+0.0001(x)$ \\
\hline \multirow{2}{*}{ Tropical Wet } & Warri & $25.62+0.02(x)^{*}$ & $25.82+0.02(x)^{*}$ & $0.20+0.001(x)^{*}$ \\
\hline & Port Harcourt & $24.89+0.02(x)^{*}$ & $22.06+0.10(x)^{*}$ & $0.15+0.0001(x)^{*}$ \\
\hline
\end{tabular}

Linear trend of the asterisked $\left(^{*}\right)$ row is significant at the corresponding station within $95 \%$ confidence level $(p \leq 0.05)$

showed potential for physiologic stress at many meteorological stations in Nigeria. Features in the Nigerian urban centres which encouraged heat related physiologic stress include the extensive transport and commercial activities in the regions [34]. Studies have equally indicated that the Nigerian climate is often affected by the movements of the Intercontinental tropical discontinuity, ITD, prevailing air masses, relief, continentality, proximity of river bodies, and anthropogenic factors, including urbanisation, gas flaring activities among others $[28,32,35,36]$. Commercial activities, transportation and industry are growing in many parts of Nigeria, and with them administration and the human population, all of which can also impact the local climate in different regions. The day-time and night-time discrepancy in the savanna and tropical wet is supported by the difference in the relative humidity in these regions. The tropical wet regions are characterised by thick cloud, which can prevent penetration of solar energy and maximise thermal comfort in the tropical wet, especially in day-time. The savanna region exhibits lower relative humidity, and this suggest less cloud cover with the consequent high radiation (heat) in the region. Conversely, re-radiation of heat can be delayed by the thick cloud cover in the tropical wet region than will be delayed in savanna region.

In addition, the results of this study indicated that 1200-1500 LST was the most thermally stressful in Nigeria. This is typical of the tropical region where the sun is known to be directly overhead at noon before the heat accumulates and peaks shortly after. Samendra and Ayesha [37] also showed that temperatures and heat conditions usually peak at 1500 


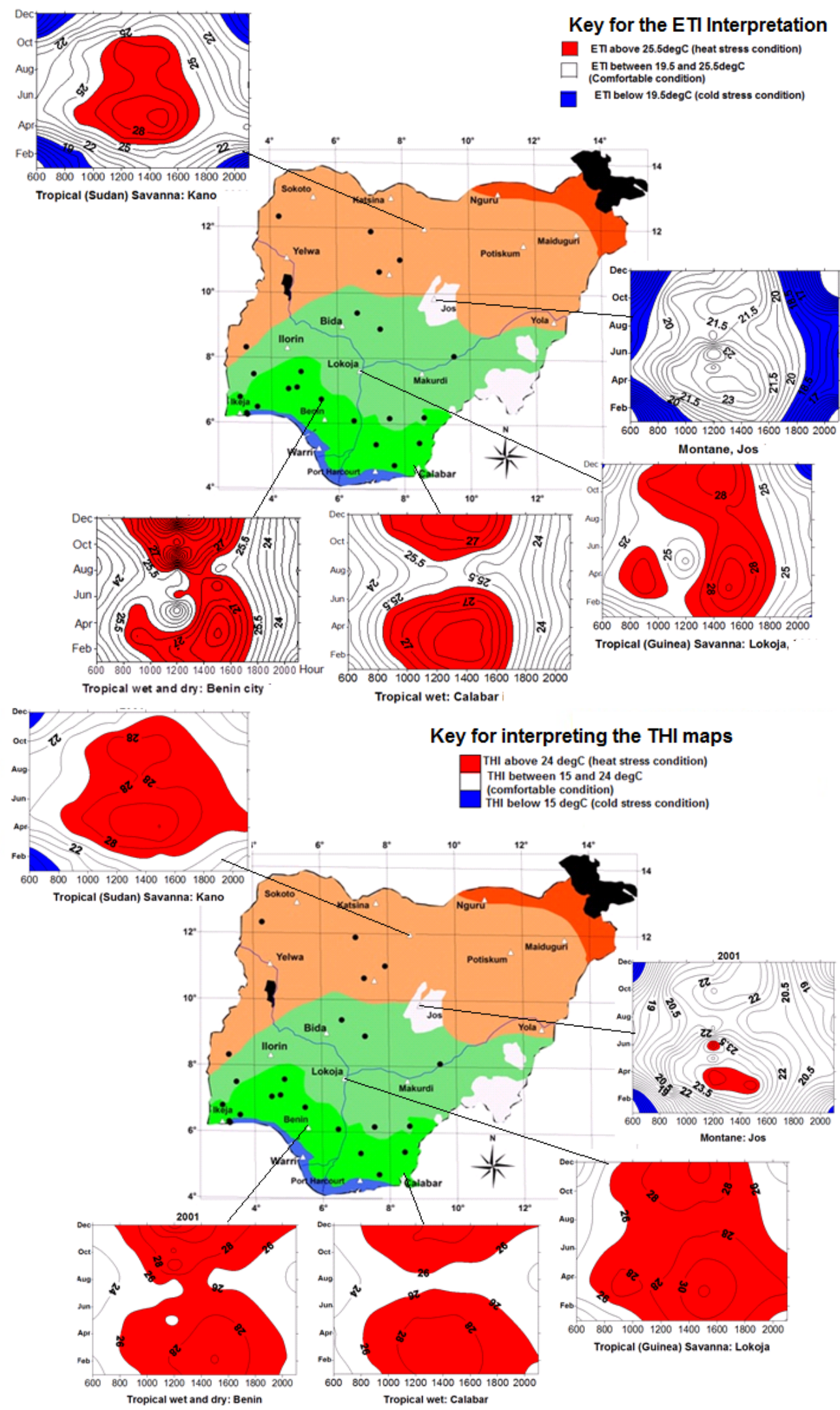

Figure 4: Representative pattern of physiologic comfort in Nigeria based on ET (a) and THI (b). 
Year 1971

0600 LST

1200 LST

1500 LST

2100 LST

Effective Temperature Index, ETI
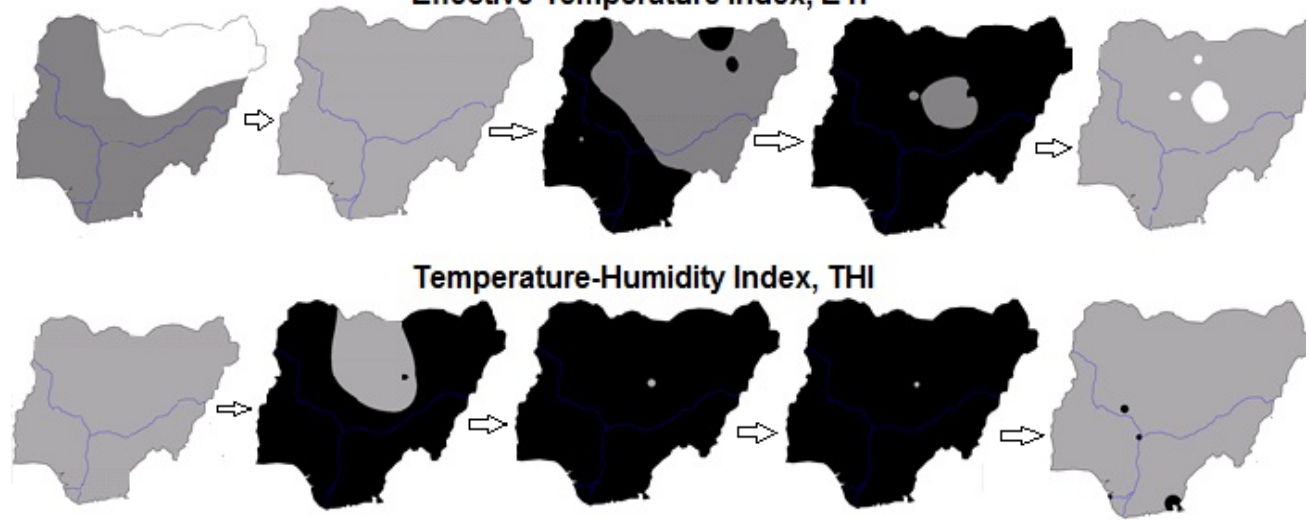

Relative Strain Index, RSI

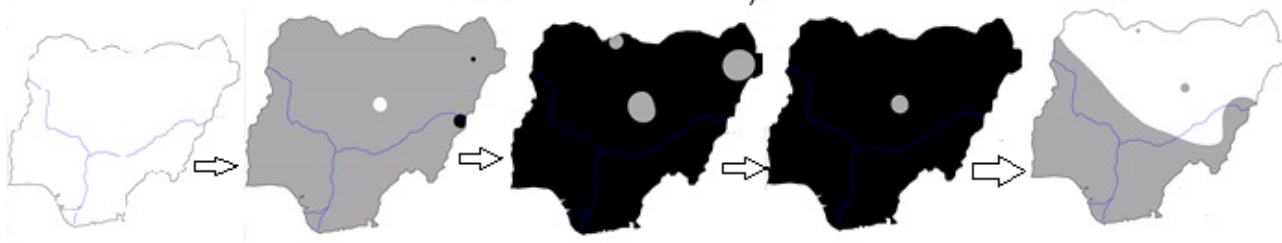

Year 2001

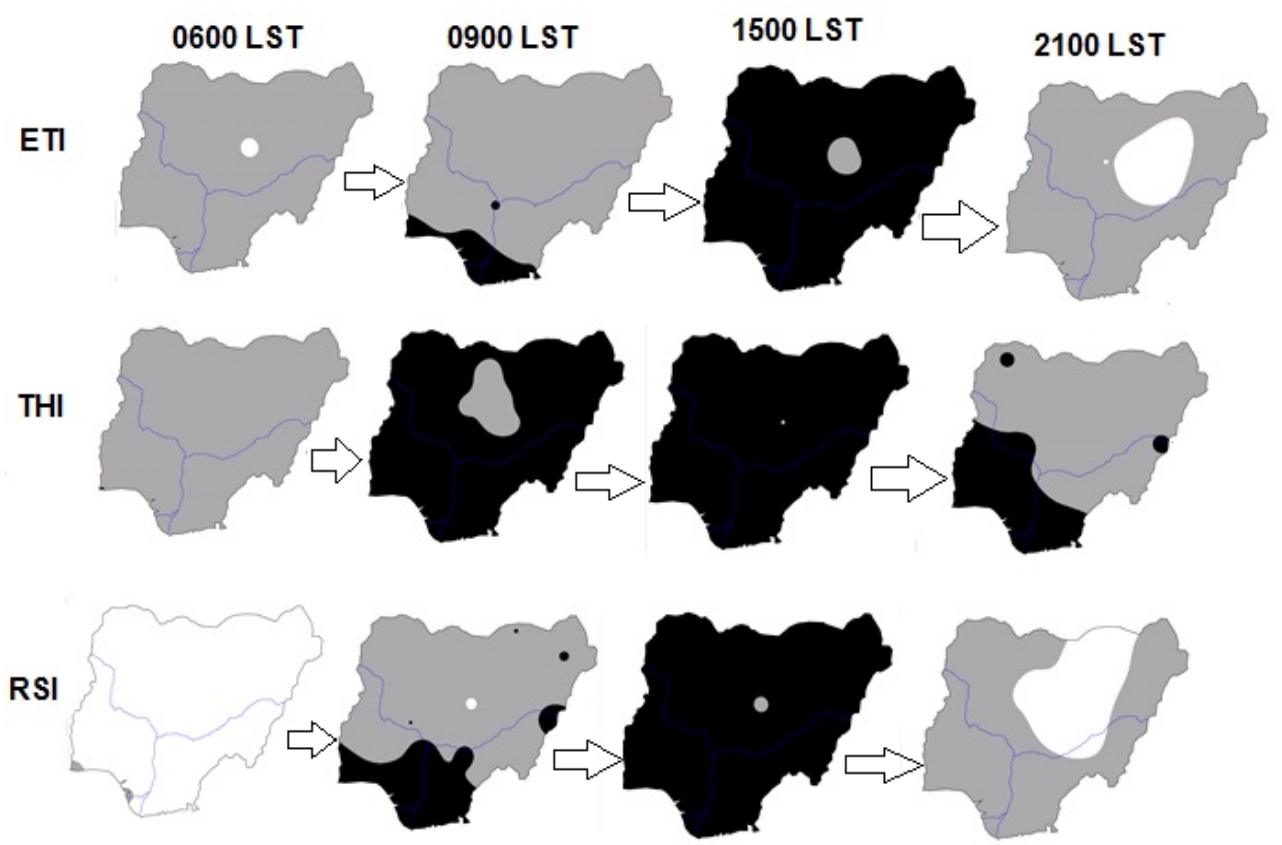

- Physiologic discomfort due to heat stress $(\mathrm{ETI}>25.6 \mathrm{deg} \mathrm{C}, \mathrm{THI}>24 \operatorname{deg} \mathrm{C}$ or $\mathrm{RSI}>0.2)$

$\square$ Physiologic comfort

Physiologic discomfort due to cold stress

$(\mathrm{ETl}<18.9 \mathrm{deg} \mathrm{C}, \mathrm{THI}<15 \mathrm{deg} \mathrm{C}$ or $\mathrm{RSI}<0.1)$

Figure 5: Mean hourly patterns of physiologic comfort in Nigeria for 1971 and 2001 (Note: Data was not available for most stations at 1200 LST in 2001 , and was therefore not mapped for the period). 

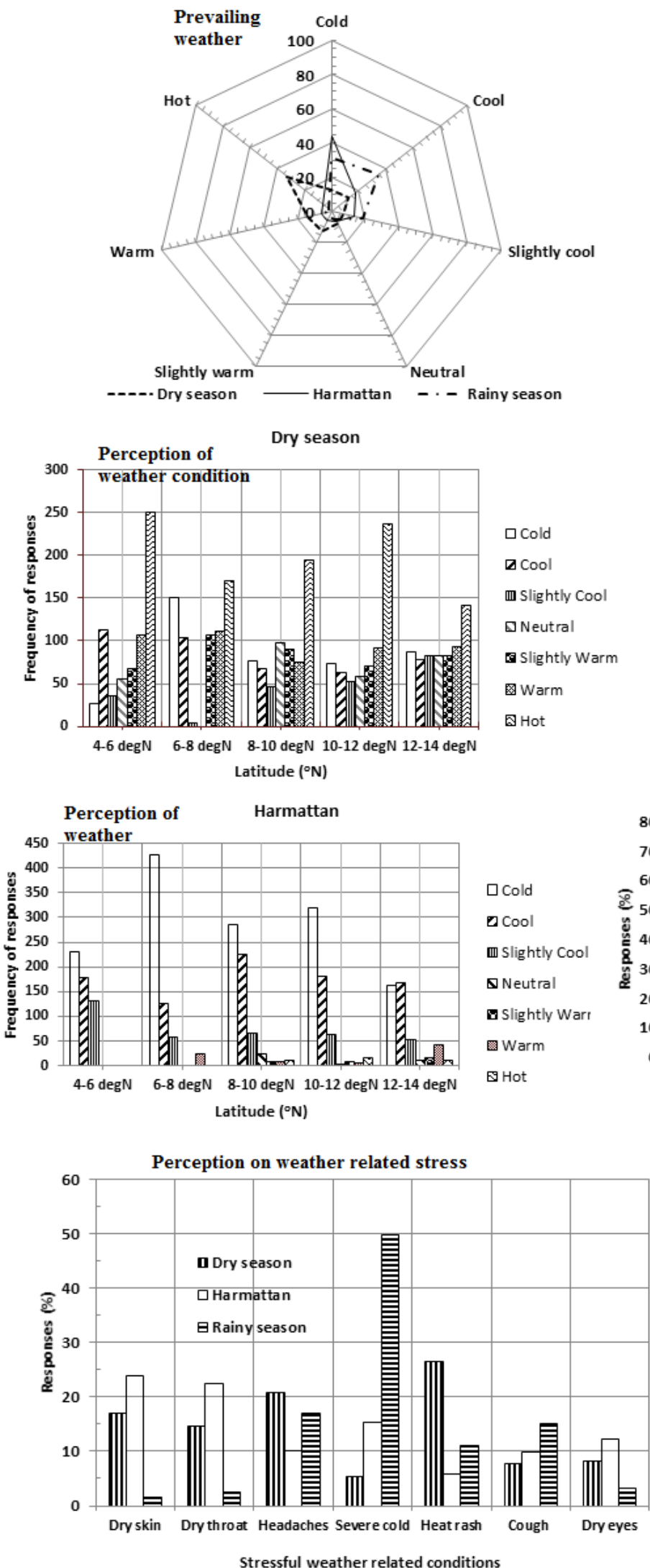
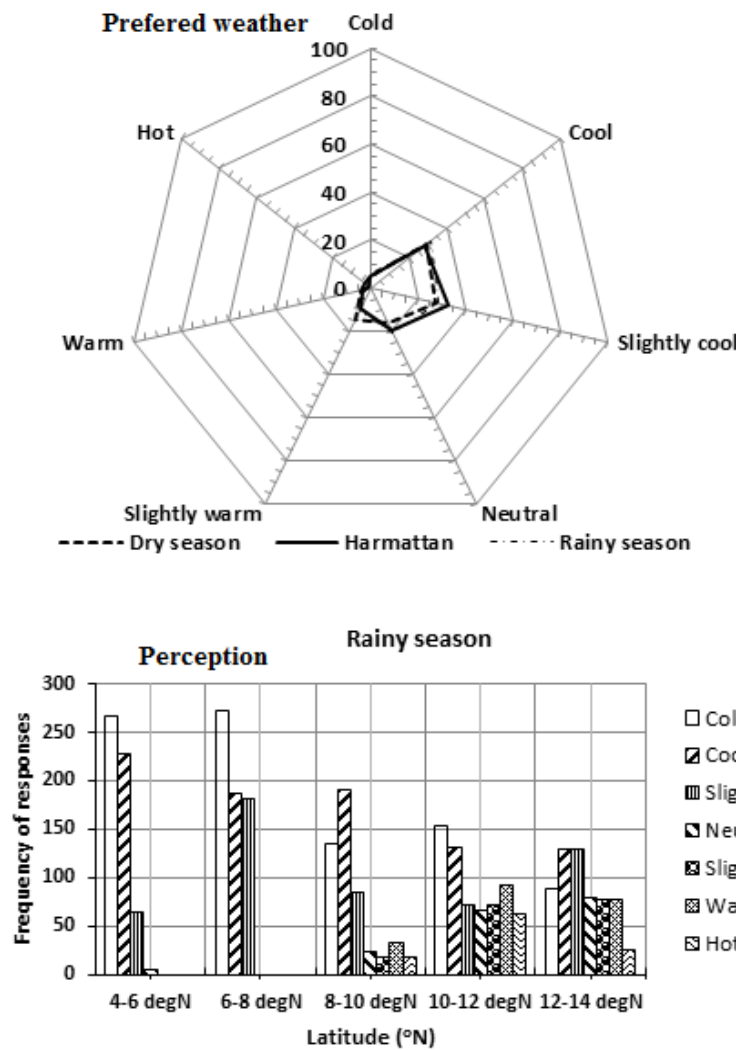

$\square$ cold

$\triangle \mathrm{Cool}$

Im Slightly Cool

D Neutral

Slightly Warm

圆 Warm

SHot

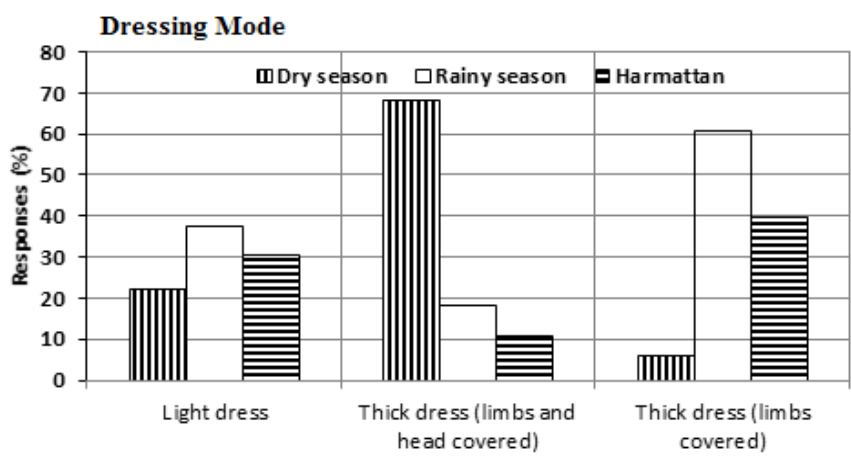

Average dressing mode in both night and daytime

Figure 6: Perceptions on weather conditions among Nigerians. 
Citation: Eludoyin OM (2015) How Well is the Tropical Africa Prepared for Future Physiologic Stress? The Nigerian Example. J Climatol Weather Forecasting 3: 133. doi:10.4172/2332-2594.1000133

a. An outdoor condition in a temperate region (Edinburgh), where people have to put on thick cloths to survive cold stress

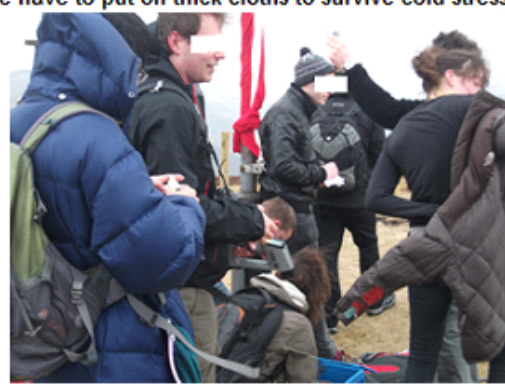

b. An outdoor condition in the tropical region where people need short sleeves shirts to cope

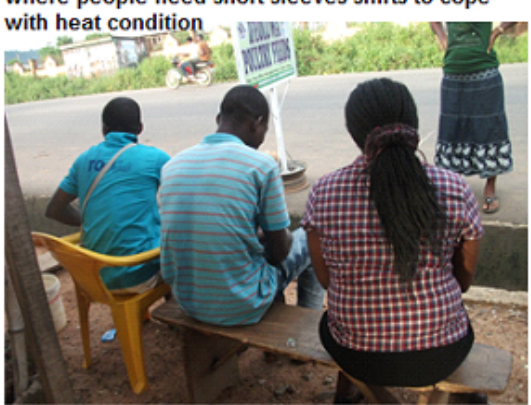

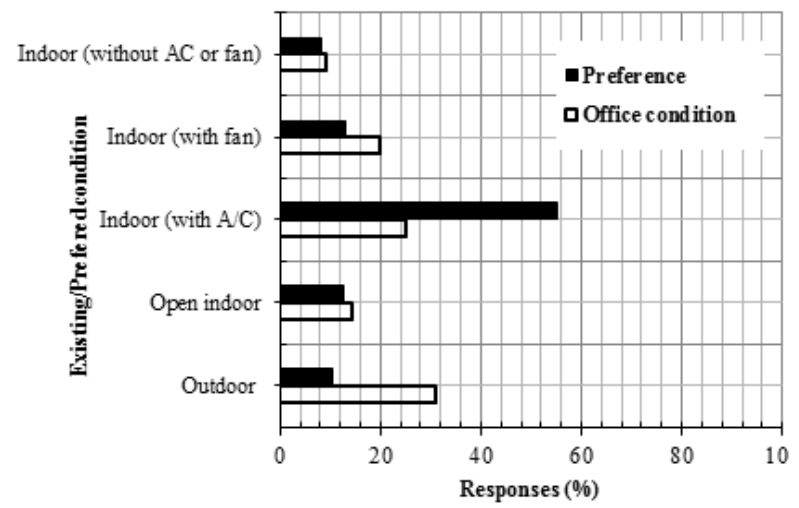

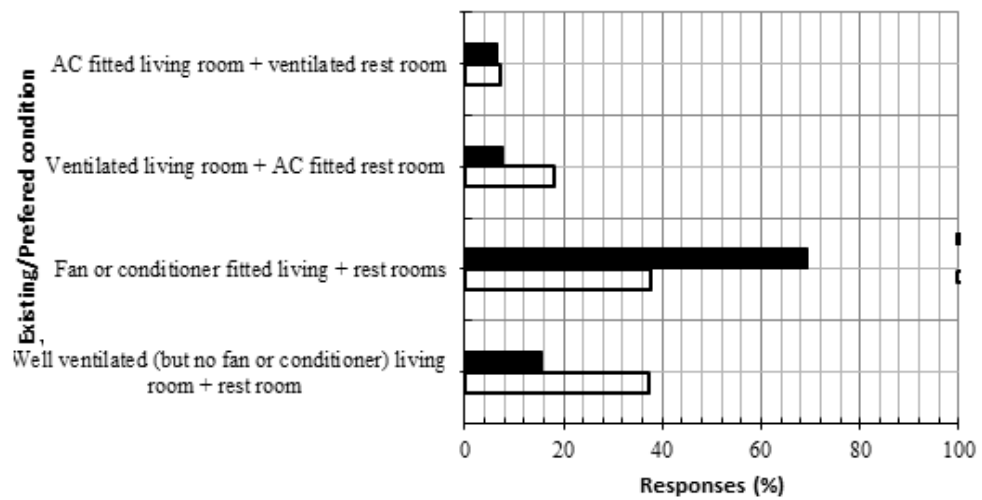

Figure 7: Coping strategies under different weather conditions.

hour in Dhaka, Bangladesh, and that more people feel uncomfortable around this hour than other hours of the day. Runnals and Oke [38] also showed that maximum heat condition occurred around this time (afternoon), and argued that the morning and night are usually more comfortable. Furthermore, the responses indicated low awareness to the morbidity and mortality consequences of extreme climate effects. Sawa and Buhari [39] has attributed the outbreak of measles and meningitis in Zaria, Nigeria in the last decade to extreme temperature while many cases of mortality were recorded as a result of heat waves in North America [22,39-41].

However, unlike the other regions which have mapped weather health-response plans $[22,40]$, Nigeria does not (as at the period of this paper) have a documented plan or any infrastructure to respond to extreme weather events, other than the National Emergency Management Agency, that has often been criticized for its inefficiency [42]. Many reports have indicated that Nigeria, like most developing countries is not prepared for the challenge of extreme climate and climate change, especially because of poor technology and poor resource allocation $[8,43,44]$. Allen [45], in a study of the assessment of the millennium development goal scores of Ondo State (in the southwest Nigeria) indicated that most states in Nigeria will poorly perform in the areas of sanitation, water supply and health. Given the results of the peoples' perceptions on thermal climate in Nigeria, it can be generally deduced that poor climate education and sensibility, poor technology (for cost effective, cheap and energy saving devices), unequal distribution of financial wealth, poor social welfare schemes (and where they exist, some of the programmes are poorly implemented and severely infested by corrupt or discriminatory practices) are the bane of social infrastructure in Nigeria.

\section{Conclusions and Recommendations}

This study has examined the thermal comfort in Nigeria and the responses to thermal stress. The study showed that thermal stress will increase in many parts of Nigeria as indicated by results of the linear regression on 59 years data, probably due to increasing rate of urbanization, population and the global temperature increase. The study however does not indicate adequate indigenous approach of physiologic stress among the people within the community of tertiary education, and there is no evidence to indicate any preparation to cope with future physiologic stress. The study recommends institutional approach towards a high level preparation for future heat stress, and this including developing a climate-oriented healthcare systems in Nigeria. This study shows the typical issues on future physiologic stress in many developing countries in the tropical region.

\section{References}

1. Lee DHK (1953) Physiological climatology as a field of study. Annals of the Association of American Geographers 43: 127-137.

2. Alcamo J, Moreno JM, Novaky B, Bindi M, Corobov R, et al. (2007) Climate Change 2007: Impacts, Adaptation and Vulnerability. In: Parry ML, Canziani OF, Palutikof JP, van der Linden PJ, Hanson CE (eds.), Contribution of Working Group II to the Fourth Assessment Report of the Intergovernmental Panel on Climate Change. Cambridge University Press, pp. 541-580.

3. Smith JB, Schneider SH, Oppenheimer M, Yohe GW, Mastrandrea MD, et al. (2009) Assessing dangerous climate change through an update of the Intergovernmental Panel on Climate Change (IPCC) reasons for concern. Proceedings of the National Academy of Sciences 106 : 4133-4137.

4. Terjung W (1967) The geographical application of some selected physioclimatic indices to Africa. International Journal of Biometeorology 11: 5-19. 
Citation: Eludoyin OM (2015) How Well is the Tropical Africa Prepared for Future Physiologic Stress? The Nigerian Example. J Climatol Weather Forecasting 3: 133. doi:10.4172/2332-2594.1000133

5. Jauregui E (1993) Urban bioclimatology in developing countries. Experientia 49: $964-968$

6. Matzarakis A, Amelung B (2008) Physiological Equivalent Temperature as Indicator for Impacts of Climate Change on Thermal Comfort of Humans. Seasonal Forecasts, Climatic Change and Human Health 30: 161-172.

7. Boko M, Niang I, Nyong A, Vogel C, Githeko A et al. (2007) ClimateChange 2007: Impacts, Adaptation and Vulnerability, Contribution of Working Group II. In: Canziani OF, Parry ML, Palutikof JP, van der Linden PJ, Hanson CE (eds.) Fourth Assessment Report of the Intergovernmental Panel on Climate Change. Cambridge University Press, Cambridge, pp. 433-467.

8. United Nations Population Fund (2007) UNFPA. The state of world population 2007: Unleashing the potential of urban growth, UNFPA, USA, pp. 32.

9. De Dear R, Fountain M (1994) Field experiments on occupant comfort and office thermal environments in a hot-humid climate. ASHRAE Transactions 100: 457-475.

10. Wong NH, Khoo SS (2003) Thermal comfort in classrooms in the tropics. Energy and Buildings 35: 337-351.

11. Unger J (1999) Comparisons of urban and rural bioclimatological conditions in the case of a Central-European city. International Journal of Biometeorology 43: $139-144$

12. Smoyer KE, Rainham GC, Hewko JN (2000) Heat-stress-related mortality in five cities in Southern Ontario: 1980-1996. International Journal of Biometeorology 44: 190-197.

13. Terjung WH (1966) Physiologic Climates of the Conterminous United States: A Bioclimatic Classification Based on Man. Annals of the Association of American Geographers 56: 141-179.

14. Gregorczuk M, Cena K (1967) Distribution of effective temperature over the surface of the earth. International Journal of Biometeorology 11: 145-149.

15. Peel C (1958) Thermal conditions in traditional mud dwellings in northern Nigeria. The Journal of Tropical Medicine and Hygiene 61: 189-203.

16. Peel C (1961) Thermal comfort zones in Northern Nigeria: an investigation into the physiological reactions of nursing students to the thermal environment. The Journal of Tropical Medicine and Hygiene 64: 113-121.

17. Ayoade J (1978) Spatial and seasonal patterns of physiologic comfort in Nigeria. Theoretical and Applied Climatology 26: 319-337.

18. Eludoyin OM, Adelekan IO (2013) The physiologic climate of Nigeria. Int $J$ Biometeorol 57: 241-264.

19. Eludoyin OM, Adelekan IO, Webster R, Eludoyin AO (2014) Air temperature relative humidity, climate regionalization and thermal comfort of Nigeria. International Journal of Climatology 34: 2000-2018.

20. Alessandro A, de Garín A (2003)A study on predictability of human physiological strain in Buenos Aires City. Meteorological Applications 10: 263-271.

21. lordache MC, Cebuc I (2009) Analysis of the impact of climate change on tourism in some European countries. Analele Stiintifice ale Universitatii' Alexandru loan Cuza" din lasi-Stiinte Economice 56: 270-286.

22. Smoyer KE (1998) A comparative analysis of heat waves and associated mortality in St. Louis, Missouri--1980 and 1995. Int J Biometeorol 42: 44-50.

23. Rainham DGC, Smoyer-Tomic KE (2003) The role of air pollution in the relationship between a heat stress index and human mortality in Toronto. Environmental Research 93: 9-19.

24. Holmer I (2004) Cold but comfortable? Application of comfort criteria to cold environments. Indoor Air 14: 27-31.
25. de Freitas CR (2003) Tourism climatology: evaluating environmental information for decision making and business planning in the recreation and tourism sector. Int J Biometeorol 48: 45-54.

26. Emmanuel R (2005) Thermal comfort implications of urbanization in a warmhumid city: the Colombo Metropolitan Region (CMR), Sri Lanka. Building and Environment 40: 1591-1601.

27. United Nations Statistics Division UNSD (2013) World Statistics Pocketbook Country Profile, Nigeria.

28. Olaniran O (1982) The physiological climate of Ilorin, Nigeria. Theoretical and Applied Climatology 31: 287-299.

29. Busch JF (1992) A tale of two populations: thermal comfort in air-conditioned and naturally ventilated offices in Thailand. Energy and Buildings 18: 235-249.

30. Davis RE, Knappenberger PC, Michaels PJ, Novicoff WM (2004) Seasonality of climate-human mortality relationships in US cities and impacts of climate change. Climate Research 26: 61-76.

31. Githeko A, Woodward A (2003) International consensus on the science of climate and health: the IPCC Third Assessment Report. Climate change and human health: risks and responses: 43-60.

32. lloeje NP (2001) A new geography of Nigeria. New Revised Edition, Longman Nig. Ltd, pp. 200.

33. Le Treut H, Somerville R, Cubasch U, Ding Y, Mauritzen C (2007) Historical overview of climate change. Earth Chapter 1, Cambridge University Press, pp. 93-127.

34. Akinbode OM, Eludoyin AO, Fashae OA (2008) Temperature and relative humidity distributions in a medium-size administrative town in southwes Nigeria. J Environ Manage 87: 95-105.

35. Adebayo $Y$ (1991) Day-time effects of urbanization on relative humidity and vapour pressure in a tropical city. Theoretical and applied climatology 43: 17-30

36. Ayoade J (1983) Introduction to Climatology for the Tropics. Wiley 4: 258.

37. Samendra K, Ayesha K (1994) The variability and probability extremes of some climatic elements over Dhaka. Reports of the Technical Conference on Tropical Urban Climates, Dhaka, Bangladesh.

38. Runnals KE, Oke TR (2000) Dynamics and control of the near-surface heat Island of Vancouver, British Columbia. Physical Geography 21: 283-304.

39. Sawa B, Buhari B (2011) Temperature Variability and Outbreak of Meningitis and Measles in Zaria, Northern Nigeria. Research Journal of Applied Sciences, Engineering and Technology 3: 399-402.

40. Kalkstein LS, Jamason PF, Greene JS, Libby J, Robinson L (1996) The Philadelphia hot weather-health watch/warning system: development and application, summer 1995. Bulletin of the American Meteorological Society 77 : 1519-1528.

41. Smoyer-Tomic KE, Rainham DG (2001) Beating the heat: development and evaluation of a Canadian hot weather health-response plan. Environ Health Perspect 109: 1241-1248.

42. Omodanisi ES, Eludoyin AO, Salami AT (2014) A multi-perspective view of the effects of a pipeline explosion in Nigeria. International Journal of Disaster Risk Reduction 7: 68-77.

43. United Nations Environment Programme (2002) UNEP. Global Environment

44. World Health Organisation WHO (2011) Regional consultation on health of the urban. Proceedings of the 2010 Regional cponsultation of Mubai, India Regional Office for South East Asia, UNFPA, pp. 82.

45. Allen AA (2013) Population dynamics and infrastructure: meeting the millennium development goals in Ondo State, Nigeria. African Population Studies 27: 229-237. 